\title{
TOTAL PHYSICAL RESPONSE (TPR) \\ UNTUK MENINGKATKAN TEKNIK MAHARAH AL-KALAM PADA SISWA MADRASAH IBTIDAIYAH
}

\author{
Rodifatul Chasanah ${ }^{1}$
}

\section{Abstrak}

Teach Arabic to motivated Arabic learning students in tpr. While usually thought of as a powerful language learning approach for beginning students, TPR actually has great potential for learners at any level of ability. The basic idea behind Total Physical Response is that a language learner learns to hear something in the language and then physically respond to it. This method was designed to accelerate listening comprehension of a foreign language by having subjects give a physical response when they heard a foreign utterance. This suggested that perhaps listening training should be continued for a long time without an attempt to speak before the student is asked to make any utterance in the foreign language.

Key note : Total Physical Response, Maharah Al-Kalam di Madrasah Ibtidaiyah

\section{A. Pendahuluan}

Bahasa masih diyakini menjadi salah satu instrumen yang cukup fundamental dalam menentukan pencapaian beragam keberhasilan dan memiliki peran sentral khususnya dalam perkembangan intelektual, sosial, dan emosional seseorang. Cukup beralasan manakala dalam dunia pendidikan, bahasa diharapkan membantu peserta didik mengenal dirinya, budayanya dan budaya orang lain, mengemukakan gagasan dan perasaan, berpartisipasi dalam masyarakat, menemukan serta mengkonstruksi kemampuan analitis dan imaginatif dalam dirinya.

Pada titik inilah betapa tidak dapat dihindari tindakan pertama dan paling penting dilakukan manusia sebagai makhluk sosial melalui bahasa adalah berkomunikasi yang berguna sebagai media

1 Dosen PPBA Universitas Islam Negeri Maulana Malik Ibrahim Malang, email:diefa_ el-fath@yahoo.com 
mempertukarkan pengalaman, mengemukakan dan menerima pikiran, mengutarakan perasaan, atau saling mengekspresikan maupun menyetujui sebuah pendirian. Pada gilirannya, bahasa pun menjadi alat komunikasi paling dominan, yang karenanya penyelenggaraan kegiatan pembelajaran bahasa melalui beberapa keterampilannya seperti mendengar, berbicara, membaca, dan menulis menjadi kompetensi yang harus dikuasai karena diyakini akan sangat menunjang seseorang dalam berbagai sektor kehidupan terlebih lagi di era global ini.

Menjadi terang bahwa salah satu fungsi utama bahasa adalah sebagai alat komunikasi untuk menyampaikan gagasan, pendapat dan perasaan kepada orang lain. Melalui bahasa manusia dapat saling berhubungan (berkomunikasi), saling berbagai pengalaman, saling belajar dari yang lain, dan meningkatkan kemampuan intelektual. Sungguhpun demikian penguasaan dan penggunaan bahasa sebagai alat komunikasi yang baik dan benar belum selalu memuaskan. Dalam perhatian Larry, Gilbert King, \& Bill (2004: 78) masih ada sejumlah peserta didik yang selalu ragu untuk berbicara. Ada rasa takut berbicara kalau mengatakan hal yang salah atau mengatakan hal yang benar dengan cara yang salah.

Adalah kian meyakinkan, dalam komunikasi lisan, dari sekian keterampilan dalam pembelajaran bahasa itu, keberadaan keterampilan berbicara seperti diyakini (Fachrurrozi, dan Mukhshon : 14) menjadi keterampilan khusus, dan menempati peran paling strategis, karena bereduksi menjadi suatu bentuk perilaku manusia yang memanfaatkan faktor-faktor fisik, psikologis, neurologis, semantik, dan linguistik sedemikian ekstensif, secara luas sehingga dapat dianggap sebagai alat manusia yang paling penting bagi kontrol sosial. Setidaknya berangkat dari penjelasan yang cukup reasionable inilah menurut Iskandarwassid, dan Dadang Sunendar (2008 : 241) menjadikan keterampilan berbicara harus dimiliki peserta didik sehingga memiliki kemampuan untuk mereproduksi arus sistem bunyi artikulasi untuk menyampaikan kehendak, kebutuhan perasaan, dan keinginannya kepada orang lain.

Demikian halnya dengan keterampilan berbicara dalam Bahasa Arab, terlihat misalnya selain keberadaannya termasuk dalam rumpun bahasa Semit yang maju, bahasa arab seperti ditegaskan 
Umam (2006:9) juga sebagai bahasa al-Qur'an, bahkan kosakata dalam bahasa Indonesia juga banyak yang menyerap dari bahasa Arab, dan disinilah keberadaanya berpengaruh dalam pasang surut peradaban dunia. Menjadi sangat beralasan apabila Bahasa Arab menjadi salah satu pelajaran dalam kegiatan pendidikan di negeri ini, yang kemudian secara konseptual, pembelajaran Bahasa Arab didefinisikan dengan:

$$
\begin{aligned}
& \text { اللغة هي الوسيلة العظمى لضم صفوف الامة الواحدة. وجمع كلمة افردها, كما أنّا أداة } \\
& \text { للتعبير عمّا يفكّر المرأ. والة لعرض ما ينتجه العقل, وهي وسيلة التفاهم بين إفراد الجما عة الوا حدة } \\
& \text { (على رضا, المرجع في اللغة العرا بية فن نهوها وصرفها, ) }
\end{aligned}
$$

Melalaui definisi tersebut secara sederhana dapat dipahami bahwa pembelajaran bahasa Arab adalah proses interaksi peserta didik dengan lingkungannya (dalam hal ini adalah bahasa Arab) sehingga terjadi perubahan perilaku siswa dimana mereka dapat memahami, mengerti, dan menguasai keterampilan bahasa Arab yang meliputi menulis, membaca, mendengarkan, berbicara dengan baik dan benar.

Kian terang bahwa Bahasa Arab merupakan mata pelajaran yang mengembangkan ketrampilan berkomunikasi lisan dan tulisan untuk memahami dan mengungkapkan informasi, pikiran, persaaan serta mengembangkan ilmu pengetahuan, teknologi dan budaya. Keseluruhan aspek pembelajaran Bahasa Arab meliputi menyimak, berbicara, membaca dan menulis saling berhubungan, misalnya, ketrampilan mendengarkan memberikan kontribusi terhadap perkembangan berbicara, kedua kemampuan tersebut diperkuat oleh kemampuan membaca, semantara ketrampilan menulis memberikan kontribusi pada ketrampilan membaca daam bentuk teks atau dokumentasi.

Keterampilan berbicara dalam pembelajaran bahasa yang diyakini menempati peran utama dalam komunikasi juga tidak dapat dihindari dalam pembelajaran bahasa Arab yang disebut dengan Maharah al-Kalam, yang secara bahasa sepadan dengan istilah speaking skill dalam bahasa Inggris dimana arti sederhananya dipahami sebagai keterampilan berbicara. Sementara berbicara dimaknai sebagai 
kemampuan mengucapkan bunyi-bunyi artikulasi atau kata-kata untuk mengekspresikan, menyatakan serta menyampaikan pikiran, gagasan, dan perasaan, maka Maharah al-Kalam adalah kemampuan seseorang untuk mengucapkan artikulasi bunyi-bunyi Arab (ashwath 'arabiyyah) atau kata-kata dengan aturan-aturan kebahasaan (qawa'id nahwiyyah wa sharfiyyah) tertentu untuk menyampaikan ide-ide dan perasaan. Karena itu pengajaran bahasa Arab bagi non-Arab pada tahap awal seperti digambarkan Fachrurrozi dan Erta (2011 : 129-130) bertujuan, antara lain, supaya siswa bisa mengucapkan bunyi-bunyi Arab dengan benar (khususnya yang tidak ada padanannya pada bahasa lain) dan dengan intonasi yang tepat, bisa melafalkan bunyibunyi huruf yang berdekatan, bisa membedakan pengucapan harakat panjang dan pendek, mampu mengungkapkan ide dengan kalimat lengkap dalam berbagai kondisi, mampu berbicara dengan kalimat sederhana dengan nada dan intonasi yang sesuai, bisa berbicara dalam situasi formal dengan rangkaian kalimat yang sederhana dan pendek, serta mampu berbicara dengan lancar seputar topik-topik yang umum.

Sementara itu, keberhasilan belajar bergantung pada beragam faktor pendukung, seperti siswa, guru dan metode yang digunakan dalam pembelajaran untuk mempermudah dalam menguasai ilmu pengetahuan kebahasaan, sehingga tidak jarang dijumpai kesulitan jika dalam proses belajar tidak sesuai dengan karakteristik metodenya. Berangkat dari itu, metode pembelajaran Bahasa Arab mendapat perhatian para ahli pembelajaran Bahasa dengan melakukan berbagai kajian dan peneitian untuk mengetahui efektifitas berbagai metode pembelajaran.

\section{B. Konstruksi Maharah al-Kalam; Formulasi, Teknik dan Strategi Pembelajaran}

\section{Pengertian Maharah al-Kalam}

Secara terminologi, Maharah al-Kalam adalah kemampuan mengungkapkan bunyi-bunyi artikulasi atau kata-kata untuk mengekspresikan pikiran berupa ide, pendapat, keinginan, atau perasaan kepada lawan bicara. Dalam makna yang lebih luas, berbicara Tarigan \& Heri Guntur (1994 : 15) menurut merupakan suatu sistem tanda-tanda yang dapat didengar dan dilihat yang memanfaatkan 
sejumlah otot dan jaringan otot tubuh manusia untuk menyampaikan pikiran dalam rangka memenuhi kebutuhannya.

Pada hakekatnya maharah al-kalam merupakan kemahiran menggunakan bahasa yang paling rumit, yang dimaksud dengan kemahiran berbicara adalah kemahiran mengutarakan buah pikiran dan perasaan dengan kata-kata dan kalimat yang benar, ditinjau dari sistem gramatikal, tata bunyi, di samping aspek maharah berbahasa lainnya yaitu menyimak, membaca, dan menulis.

Kemampuan berbicara (maharah al-kalam) dijelaskan Imam (2009: 22) didasari oleh; kemampuan mendengarkan (reseptif), kemampuan mengucapan (produktif), dan pengetahuan (relative) kosa-kata dan pola kalimat yang memungkinkan siswa dapat mengkomunikasikan maksud/fikirannya. Secara umum maharah al-kalam bertujuan agar mampu berkomunikasi lisan secara baiok dan wajar dengan bahasa yang mereka pelajari. Secara baik dan wajar mengandung arti menyampaikan pesan kepada orang lain dalam cara yang secara sosial dapat diterima. Sasaran teknik ini memberikan kesempatan kepada peserta didik untuk menggunakan bahasa Arab pada situasi yang alami dengan sikap spontanitas kreatif, disamping penguasaan tata bahasa. Lebih fokusnya adalah menyampaikan makna atau maksud yang tepat sesuai dengan tuntunan dan fungsi komunikasi pada waktu tertentu.

Kemahiran berbicara (maharah al-kalam) merupakan salah satu kemahiran berbahasa yang aktif-produktif, kemampuan berbicara menuntut penguasaan terhadap beberapa aspek dan kaidah penggunaan bahasa (Djiwandono, 1996). Secara umum, proses pembelajaran maharah kalam tidakjauh berbeda dengan pembelajaran kemahiran berbahasa lainnya yang bersifat gradual. Namun masingmasing dari maharah memiliki ciri dalam proses pembelajarannya. Oleh karena itu dalam makalah ini akan dibahas secara umum tentang Pendekatan, Metode, Strategi, dan Teknik Pembelajaran Maharah Kalam yang diharapkan mampu memberikan kemudahan dan pemahaman bagi para pendidik maupun peserta didik dalam proses pembelajaran Maharah al-kalam. 


\section{Pendekatan Pembelajaran Maharah al-kalam}

Pendekatan (Madkhal/ approach) adalah seperangkat asumsi berkenaan dengan hakikat bahasa dan belajar mengajar bahasa bersifat aksiomatis. Berikut adalah paparan tentang macam-macam pendekatan, diantaranya adalah :

1) Pendekatan Humanistik (Humanistic Approach)

Pendekatan ini memberi tempat yang utama pada peserta didik karena mereka adalah subjek utama dalam kegiatan pendidikan. Pendekatan ini berasumsi bahwa peserta didik memiliki potensi, kekuatan, dan kemampuan untuk berkembang serta memiliki kebutuhan emosional, spiritual, dan intelektual yang harus diperhatikan. Penyampaian materi tidak dijadikan sebagai suatu yang menekan, membebani, melainkan bagaimana penguasaan bahasa menjadi kebutuhan peserta didik sebagaimana kebutuhan lainnya. Langkah pertama untuk merealisasikan tujuan hal itu adalah memberikan kesempatan kepada peserta didik untuk bercakap tentang diri dan perasaannya serta bergantian mengungkapkan berbagai hal mengenai diri mereka. Proses ini bisa memenuhi kebutuhan pembelajar untuk aktualisasi diri.

2) Pendekatan Teknik (Media-Based Approach)

Pendekatan yang didasarkan pada pemanfaatan media pembelajaran dan teknik-teknik pendidikan. Pendekatan ini berpendapat bahwa media dan teknik pembelajaran sangat berperan dalam menyampaikan pengalaman belajar serta bisa mengubah pengalaman belajar menjadi pengalaman yang nyata (terindra). Pendekatan ini bertujuan untuk memberikan cara untuk menjelaskan materi - materi dengan menggunakan gambar-gambar, peta, lukisan, menghadirkan contoh yang nyata, kartun dan lain sebagainya yang sekiranya dapat membantu memahamkan siswa tentang pesan-pesan kata bahasa asing.

3) Pendekatan Mendengar-Mengucapkan (Aural Oral Approach)

Pendekatan ini mengandaikan bahwa bahasa adalah apa yang didengar dan diucapkan, bukan simbol. Sedangkan tulisan hanyalah representasi dari ujaran. Dari asumsi ini dapat dikatakan bahwa bahasa adalah ujaran. Pembelajaran bahasa harus dimulai dengan mendengarkan bunyi-bunyi bahasa yang berbentuk kata 
dan kalimat. Jadi pendidik meminta peserta didiknya menirukan pelafalan kata/kalimat untuk dihafal, sebelum membaca dan menulis diajarkan. Asumsi lain dari pendekatan ini bahwa bahasa adalah kebiasaan. Suatu prilaku akan menjadi kebiasaan apabila diulang berkali-kali. Oleh karena itu, pembelajaran bahasa Arab dengan pendekatan aural oral approach ini menuntut adanya kegiatan pembelajaran bahasa yang dilakukan dengan teknik pengulangan atau repetisi.

4) Pendekatan Komunikatif (Communicative Approach)

Pendekatan yang menitikberatkan pengajaran bahasa secara konunikatif artinya pengajaran yang dilandasi oleh teori komunikatif atau fungsi bahasa. Tujuan pengajaran bahasa dalam pendekatan ini adalah untuk mengembangkan kemampuan komunikatif serta prosedur pengajaran ketrampilan berbahasa yang saling memiliki ketergantungan antara bahasa dan komunikasi. Menurut Hymes, terdapat empat faktoryang menjadi pembangun dan menjadi ciri penanda kompetensi komunikatif ini, yaitu kegramatikalan (penguasaan tata bahasa secara baik), keberterimaan (saling dapat dipahami dan memahami), ketepatan (konteks dengan situasi yang berkembang), dan keterlaksanaan (praktik yang dilakukan secara terus-menerus). Tujuan pengajaran bahasa adalah untuk menolong pembelajar mencapai kemampuan komunikatif.

\section{Metode Pembelajaran Maharah al-kalam}

Metode (Thariqah/Method) dijelaskan Murtadho (2008: 221) adalah perencanaan secara menyeluruh yang terkait dengan penyajian bahan ajar bahasa secara sistematis dan bersifat prosedural digunakan untuk mencapai tujuan pembelajaran yang diharapkan. Berikut metodemetode yang telah berkembang dalam pembelajaran, yaitu

1) Metode Nahwu wa tarjamah

Penerapan metode ini banyak menekankan pada penggunaan nahwu (tata bahasa) dan praktik penerjemahan dari bahasa dan ke dalam bahasa sasaran. Metode ini bahkan harus kita akui sebagai metode yang paling populer digunakan dalam pembelajaran bahasa baik di sekolah, pesantren maupun di perguruan tinggi. 
2) Tharigah Mubassyaroh (Metode Langsung/Direct Method)

Metode ini lahir sebagai reaksi terhadap penggunaan metode nahwu wa tarjamah yang mengajarkan bahasa seperti bahasa yang mati. Metode ini memberikan banyak waktu untuk melatih keterampilan berbicara sebagai ganti dari keterampilan membaca, menulis, dan menterjemahkan. Dalam prakteknya, metode ini selalu mengaitkan antara kata-kata yang diajarkan menggunakan model meniru dan menghapal dengan objek-objek yang ditunjuk oleh kata-kata tersebut, antara suatu kalimat dengan situasi yang diungkapkannya. Dengan demikian metode ini dinamakan metode langsung.

3) Thariqah Sam'iyah Syafawiyah (Audio Lingual Method)

Beragam asumsi yang mendukung dalam metode ini antara lain :

a) Essensi bahasa adalah berbicara. Sedangkan menulis merupakan bagian dari gambaran berbicara. Oleh karena itu perhatian dalam pengajaran bahasa asing hendaklah dicurahkan untuk tercapainya keterampilan berbicara, bukannya keterampilan membaca atau menulis.

b) Proses pengajaran bahasa hendaklah mengikuti urutan urutan tertentu, yaitu : mendengar, berbicara, membaca, dan menulis.

c) Metode pemerolehan bahasa adalah dengan pembentukan kebiasaan-kebiasaan dalam bahasa, yaitu dengan jalan berlatih secara bertahap.

4) Metode Eklektik

Metode ini muncul sebagai respon atas munculnya ketiga metode di atas. Asumsi-asumsi metode ini adalah :

a) Tak ada satu metode pun yang sempurna, sebagaimana halnya tidak ada satu metode pun yang salah total, sehingga setiap metode mempunyai kelebihan dan kekurangannya masing-masing.

b) Prinsip utama dalam pengajaran terpusat pada pembelajar dan kebutuhannya. Bukannya kepada metode tertentu tanpa memperhitungkan kebutuhan pembelajar. Seorang guru hendaklah merasa bebas dalam memilih metode 
yang akan digunakannya sesuai dengan kondisi siswa, dan dengan tidak menutup mata dari berbagai penemuan baru dalam metodologi pengajaran. Seorang guru mungkin dapat memilih satu metode atau beberapa metode yang sesuai dengan kebutuhan siswa dan situasi belajar-mengajar.

\section{Strategi Pembelajaran Maharah al-kalam}

Poin penting dalammendefinisikan belajartelah digariskanSlamet (2003:2) sebagai proses usaha yang diupayakan untuk memperoleh suatu perubahan tingkah laku yang baru secara keseluruhan sebagai hasil pengalamannya sendiri dengan lingkungannya. Sebaliknya, mengajar pada hakikatnyaadalah suatu proses, yakni proses mengatur, mengorganisasi lingkungan yang ada disekitar siswa sehingga dapat menumbuhkan dan mendorong siswa melakukan proses belajar mengajar. Pada tahap berikutnya mengajar didefinisikan Nana Sudjana (1989: 29) sebagai suatu proses memberikan bimbingan atau bantuan kepada siswa dalam proses belajar mengajar.

Ehlers dan Lee (1963 : 27) dalam bukunya mengatakan bahwa:

Good theaching will have to aspect. It will include the communication of positive knowledge and accepted principles a long with an analysis of the line of reasoning, or wherever appropriate, the repetition, or at least the description of the experiments by wich the conclusions were reached. The other aspect discussion of diverse view on issues stiil unstelled.

Dapat dimengerti bahwa mengajar yang baik meliputi dua aspek, yaitu terciptanya komunikasi atau memberikan suatu ilmu pengetahuan yang positif dan diterimanya sebuah analisis sebagai dasar pemikiran atau merupakan sedikit gambaran dari suatu percobaan (penelitian) yang mana kesimpulannya dapat dijangkau. Aspek yang lain adalah mendiskusikan macam-macam pendapat atau pendengaran dalam suatu hal yang belum pasti kebenarannya.

Sementara itu, kegiatan belajar mengajar dideskripsikan Suryatna Rafi'i (1985 : 52) suatu kondisi yang sengaja diciptakan, gurulah yang menciptakan nya guna membelajarkan siswa. Guru yang mengajar dan siswa belajar. Dalam kegiatan belajar mengajar, guru dan siswa 
terlibat dalam interaksi dengan bahan pelajaran sebagai medianya. Kegiatan belajar mengajar adalah proses yang bertujuan. Tujuannya tersebut dinyatakan dalam rumusan tingkah laku yang diharapkan dimiliki siswa setelah menyelesaikan pengalaman belajarnya.

Perlu diketahui bahwa proses belajar yang bermakna adalah proses belajar yang melibatkan berbagai aktivitas siswa. Untuk itu guru harus berupaya untuk mengaktifkan siswa. Sebagai salah satu komponen pembelajaran, metode mempunyai peran yang sangat penting dalam kegiatan belajar mengajar. Bahkan dapat dikatakan bahwa dalam kegiatan belajar mengajar semuanya menggunakan metode. Karena metode menurut Abdul Hamid (2008 : 3) merupakan suatu alat untuk menyajikan bahan atau materi pelajaran dalam rangka untuk mencapai tujuan pengajaran yang akan disampaikan kepada peserta didik. Sedangkan menurut Zakiyah Daradjat (tt:1) metode adalah suatu cara kerja yang sistematis dan umum, seperti cara kerja ilmu pengetahuan.

Disamping itu perlu ditegaskan bahwa pembelajaran sendiri merupakan suatu upaya yang disengaja dan direncanakan sedemikian rupa oleh pihak guru, sehingga memungkinkan terciptanya suasana dan aktivitas belajar yang kondusif bagi para siswanya. Sehingga Radliyah Zaenudin (2005 : 92) menyimpulkan bahwa proses pembelajaran merupakan dua rangkaian kegiatan yang dilakukan oleh seorang pendidik yang hal ini disebut mengajar disusul oleh kegiatan yang disebut belajar yang berlangsung pada waktu yang telah ditentukan guna mencapai tujuan tertentu.

Dari uraian tersebut diatas maka dapat disimpulkan bahwa metode pembelajaran merupakan cara yang sistematis dalam menyampaikan materi kepada siswa guna mencapai tujuan yang diinginkan, dengan melihat definisi tersebut diatas, maka tujuan metode pembelajaran adalah :

a) Memberi jalan untuk mencapai suatu tujuan pembelajaran yang ditempuh oleh guru dan siswa.

b) Memberi gambaran rencana secara meyeluruh dalam pencapaian tujuan pembelajaran secara sistematis

c) Memudahkan pencapaian tujuan pembelajaran 
Melihat dari definisi dan tujuan metode pembelajaran diatas, maka dapat disimpulkan pula metode ialah cara atau jalan yang ditempuh oleh guru untuk meyampaikan materi pelajaran kepada siswa. Karena itu setelah guru memikirkan bahan pelajaran, maka hendaklah ia memikirkan cara penyampaian bahan tersebut dalam pikiran siswa. Guru menurut Abu Bakar Muhamad (1981 : 8) harus memikirkan metode yang paling baik untuk menyusun bahan itu, dan menjadikan susunanan bahan mata pelajaran itu sebagai mata rantai sambung menyambung.

Dengan metode pembelajaran yang digunakan dapatlah memudahkan siswa belajar sesuatu yang berguna dan bermanfaat, bagaimana memadukan antara isi dan nilai yang terkandung dalam pembelajaran, dan belajar diharapkan dapat membentu siswa untuk meningkatkan kemampuan yang sesuai dengan tujuan instruksional yang ingin dicapai. Strategi merupakan rencana yang cermat mengenai kegiatan untuk mencapai sasaran khusus. Sedangkan dalam konteks pembelajaran, strategi adalah kemampuan internal seseorang untuk berpikir, memecahkan masalah, dan mengambil keputusan. Artinya bahwa proses pembelajaran akan menyebabkan peserta didik berpikir untuk menganalisis, memecahkan masalah dalam mengambil keputusan. Peserta didik akan mempunyai kontrol yang tinggi yaitu analisis yang tajam, tepat dan akurat.

Strategi sebagai dasar pembelajaran khususnya Bahasa Arab meliputi empat komponen utama yaitu:

1) Mengefektikan tujuan pembelajaran

Keaktifan belajar siswa dalam bahasa menjadi kunci, baik aktif belajar maupun pengembangan materi kebahasaan. Strategi yang diambil harus senantiasa bermuara untuk menciptakan keaktifan, baik secara fisik maupun mental, akan tetapi aktif mental lebih diutamakan.

2) Menentukan kembali pendekatan pembelajaran

Dalam belajar bahasa, seseorang diberi kebebasan untuk menggunakan strategi yang sesuai dengan situasi dan kondisi. Namun, yang perlu diperhatikan adalah strategi yang dapat menggugah semangat untuk mengembangkan ilmu yang telah diterima. Sehingga peserta didik setelah belajar merasa ilmu yang sedang dipelajari bermanfaat dan mempunyai keberanian untuk mengekspresikan ide atau gagasan kepada teman 
4) Menetapkan langkah-langkah yang ditempuh sejak awal sampai akhir.

Belajarbahasa Arabkhususnyamaharahal-kalamharus mengikuti pola tadarruj (dari yang mudah sampai ke yang sulit).

5) Menetapkan ukuran keberhasilan

Dalam strategi pembelajaran suatu kegiatan pembelajaran yang dikerjakan pendidik dan peserta didik dilakukan secara optimal agar pembelajaran dapat tercapai secara efektif dan efisien atau sesuai dengan tujuan yang ingin dicapai sebelumnya.

\section{Mengimplementasikan Total Physical Response (TPR) dalam Pembelajaran Maharotul Kalam pada Madrasah Ibtidaiyah}

\section{Pemahaman Konsep Total Physical Response (TPR)}

Total Physical Response seperti dipahami Ghazali (2010 : 96) merupakan metode pembelajaran bahasa yang menggunakan perintah-perintah lisan dengan tujuan agar siswa dapat menunjukkan pemahamannya terhadap maksud dari perintah-perintah lisan itu. Secara teknis, guru memberikan beberapa contoh melalui gerakan maupun tindakan yang diperintahkan itu sehingga siswa secara tidak langsung mendapatkan struktur tatabahasa dan kosakata dari bahasa target. Selama periode latihan menyimak, siswa diminta untuk merespon perintah dari guru, kemudian siswa berganti peran dengan gurunya memproduksi bahasa dengan cara memberikan perintah kepada teman sekelasnya bahkan dengan gurunya. Kemampuan membaca dan menulis digunakan untuk menunjang komponen lisan/ menyimak ini. Para siswa diminta untuk menuliskan semua kosakata dan struktur tatabahasa yang telah diajarkan dalam pertemuan itu pada buku tulis mereka pada akhir pelajaran. Metode ini sangat membantu untuk mempermudah guru dan siswa dalam proses pembelajaran kosakata karena metode ini juga dapat dikombinasikan dengan gambar/benda nyata dan juga gerakan tubuh, agar siswa dapat memahami dan mengekspresikannya.

Berangkat dari beberapa pengalaman yang berhasil dihimpun, diyakini bahwa pembelajaran bahasa dengan metode TPR ini disukai sebagian besar siswa, terlihat misalnya ketika siswa diminta memperagakan makna kosakata dalam proses pembelajaran, mereka 
dengan meresponnya dengan berdiri dari tempat duduknya untuk memperagakan kosakata tersebut. Selain itu, siswa juga tidak merasa bosan karena mereka belajar sambil melakukan (learning by doing), dan menurut Nurhidayati dan Ridwan (2005:10), sejalan dengan dengan salah satu karekteristik anak-anak dalam pembelajaran bahasa yaitu anak-anak belajar sambil bekerja/learning by doing.

Melalui penerapan metode TPR dalam pengajaran kosakata bahasa Arab, siswa secara langsung dapat mengetahui makna kosakata tersebut tanpa harus meraba-raba makna kosakata itu sendiri. Betapa tidak, dengan peragaan secara otomatis siswa secara langsung dapat mengetahui makna kosakata tanpa melaui metode terjemah. Disinilah nampaknya relevan dengan dengan teori perkembangan kognitif Piaget, yaitu anak-anak pada usia Madrasah Ibtidaiyah, perkembangan kognitifnya masih berada pada tahap operasi konkrit (concrete operational).

Sejauhinitelah ada beberapa macammetodeyang biasa digunakan seorang guru atau instruktur dalam meningkatkan kemampuan belajar peserta didiknya seperti metode diskusi, ceramah, inquiry dan lain-lain. Dengan maksud meyakinkan, dalam pembelajaran Bahasa Arab nampaknya metode Total Physical Response dirasa cukup efektif untuk mencapai kualitas hasil belajar yang jauh lebih baik khusunya dalam Maharotul Kalam.

\section{Pengertian Metode TPR (Total Physical Response)}

Richards J, mendefinisikan TPR dengan:

"a language teaching method built around the coordination of speech and action; it attempts to teach language through physical (motor) activity".

Metode pembelajaran bahasa yang disusun pada koordinasi perintah (command), ucapan (speech) dan gerak (action); dan berusaha untuk mengajarkan bahasa melalui aktivitas fisik (motor). Sedangkan menurut Larsen dan Diane dalam Technique and Principles in Language Teaching, TPR atau disebut juga " the comprehension approach" atau pendekatan pemahaman yaitu suatu metode pendekatan bahasa asing dengan instruksi atau perintah.

Secara historis, metode ini dikembangkan oleh James J. Asher di Universitas San Jose California dan sukses dalam pengembangan metode ini pada pembelajaran bahasa asing pada anak-anak. Ia 
berpendapat bahwa pengucapan langsung pada anak mengandung suatu perintah, dan selanjutnya akan merespon kepada fisiknya sebelum mereka memulai untuk menghasilkan respon verbal atau ucapan. Tidak mengherankan apabila kemudian metode pembelajaran ini kemudian lebih akrab sering disebut Asher Method yang artinya memakai masa waktu yang cukup untuk mendengar dan mengamati perintah sebelum seseorang diajak berbicara dalam bahasa Asing.

Secara aplikatif, metode TPR ini sangat mudah dan ringan dalam segi penggunaan bahasa dan juga mengandung unsur gerakan permainan sehingga dapat menghilangkan stress pada peserta didik karena masalah-masalah yang dihadapi dalam pelajarannya terutama pada saat mempelajari bahasa asing, dan juga dapat menciptakan suasana hati yang positif pada peserta didik yang dapat memfasilitasi pembelajaran sehingga dapat meningkatkan motivasi dan prestasi siswa dalam pelajaran tersebut. Guru atau instruktur memiliki peran aktif dan langsung dalam menerapkan metode TPR ini. Menurut Asher "The instructor is the director of a stage play in which the students are the actors", yang berarti bahwa guru (instruktur) adalah sutradara dalam pertunjukan cerita dan di dalamnya siswa sebagai pelaku atau pemerannya.Guruyang memutuskan tentang apayangakan dipelajari, siapa yang memerankan dan menampilkan materi pelajaran. Siswa dalam TPR mempunyai peran utama sebagai pendengar dan pelaku. Siswa mendengarkan dengan penuh perhatian dan merespon secara fisik pada perintah yang diberikan guru baik secara individu maupun kelompok. Adapun inti dari pendekatan awal yang digunakan adalah membuat peserta didik diam, mendengarkan perintah lalu sejalan dengan apa yang dilakukan oleh pendidik, mereka menuruti apa saja yang diperintahkan oleh pengajar tersebut. Peserta didik belajar dengan cara melakukan perbuatan secara fsik berdasar atas perintah pendidik, kemudian atas perintah teman sejawat.

\section{Bentuk Aktivitas dengan Metode TPR dalam Proses Belajar Mengajar.}

Dalam proses belajar mengajar dengan menggunakan metode TPR ini banyak sekali aktivitas yang dapat dilakukan oleh guru dan siswa antara lain:

a) Latihan dengan menggunakan perintah (Imperative Drill ), merupakan aktivitas utama yang dilakukan guru di dalam kelas 
dari metode TPR. Latihan berguna untuk memperoleh gerakan fisik dan aktivitas dari siswa.

b) Dialog atau percakapan (conversational dialogue).

c) Bermain peran (Role Play), dapat dipusatkan pada aktivitas sehari-hari seperti di sekolah, restoran, pasar, dan sebagainya.

d) Presentasi dengan alat peraga.

e) Aktivitas membaca (Reading) dan menulis (Writing) untuk menambah perbendaharaan kata (vocabularies) dan juga melatih pada susunan kalimat berdasarkan tenses dan sebagainya.

\section{Teori pembelajaran TPR}

Teori pembelajaran bahasa melalui TPR yang diterapkan pertama kali oleh Asher menyajikan beberapa hipotesa pembelajaran yang berpengaruh yaitu:

1) Terdapat bio-program bawaan yang spesifik untuk pembelajaran bahasa yang menggambarkan sebuah alur yang optimal untuk pengembangan bahasa pertama dan kedua.

2) Lateralisasi otak menggambarkan fungsi pembelajaran yang berbeda pada otak kiri dan kanan.

3) Stres mempengaruhi aktivitas pembelajaran dan apa yang akan dipelajari oleh peserta didik, stress yanglebih rendahkapasitasnya maka pembelajaran menjadi lebih baik.

Demikian tentang metode pembelajaran TPR yang saat ini kemungkinan besar agak asing sekalipun sesungguhnya bukanlah metode baru yang sekiranya lebih baik diantara metode-metode pembelajaran yang lain. Betapapun demikian ada baiknya jika metode ini dipergunakan dengan sumsi akan memberikan manfaat dalam meningkatkan motivasi belajar terutama dalam pelajaran bahas.

\section{Implementasi Total Physical Response (TPR) dalam Pembelajaran Maharotul Kalam pada Siswa Madrasah Ibtidaiyah}

Dimana setiap lembaga pendidikan mempunyai perbedaan dalam menentukan tujuan tersebut. Adapun mata pelajaran bahasa arab di madrasah ibtidaiyah memiliki tujuan sebagai berikut: 
a) Mengembangkan kemampuan berkomunikasi dalam bahasa arab, baik lisan maupun tulis yang mencakup empat kemahiran berbahasa, yakni menyimak (istima'), berbicara (kalam), membaca (qira'ah), dan menulis (kitabah).

b) Menumbuhkan kesadaran pentingnya bahasa arab sebagai salah satu bahasa asing untuk menjadi alat utama belajar, khususnya dalam mengkaji sumber-sumber ajaran islam.

c) Mengembangkan pemahaman tentang saling keterkaitan antara bahasa dan budaya serta memperluas cakrawala budaya. Dengan demikian, peserta didik diharapkan memiliki wawasan lintas budaya dan melibatkan diri dalam keragaman budaya.

Adapun tema materi bahasa arab di madrasah ibtidaiyah adalah:

a) Kelas IV Semester 1: At-Ta'âruf, al-Adawâtul-madrasiyyah, dan alMihnah; dan Semester 2: Al-'Unwân, Usratî, dan A'dlâ ul-insân;

b) Kelas V Semester 1: Fil-Bait, Fil-Hadîqah dan al-Alwân; dan Semester 2: Fil-Madrasah, fil-Ma'mal, fil-Maktabah dan fil-mqshaf;

c) Kelas VI Semester 1 : As-Sấah dan al-Af'âlul-yaumiyyah; dan Semester 2: Al-Wâjibul-manziliy.

Berkenaandengantujuandanmateripenyelenggaranpembelajaran bahasa arab di Madrasah Ibtidaiyah tersebut, teknik (Uslub/Technique) merupakan implementasi perencanaan pembelajaran di dalam kelas berupa berbagai macam strategi untuk menyajikan bahan ajar dalam rangka mencapai tujuan khusus pembelajaran. Beberapa teknik Maharah al-kalam dalam pembelajaran bahasa Arab antara lain :

1) Prakomunikatif dipahami sebagai pola aktivitas pembelajaran Maharah al-kalam yang menuntut guru lebih banyak menyediakan materi secara lebih variatif yang pada gilirannya akan membawa siswa lebih merasa belajar. Dengan beragam teknik pada tahapan prakomunikatif ini diprediksikan siswa dapat memahami pembelajaran dasar maharah al-kalam yang secara bertahap dapat dijelaskan sebagai berikut:

a) Al-hifz ala al-hiwar (hafalan dialog)

Dalam teknik ini latihan meniru dan menghafalkan dialogdialog mengenai berbagai macam situasi dan kesempatan. 
Melalui latihan ini diharapkan pelajar dapat mencapai kemahiran yang baik dalam percakapan dan latihan tersebut dilakukan secara terus-menerus.

b) Al-hiwar bil al-shuwar (dialog melalui gambar)

Melalui teknik ini diharapkan dapat memahami fakta melalui gramar yang diungkapkan secara lisan sesuai dengan tingkatan siswa, guru dalam hal ini membawa gambar-gambar dan menunjukkkan satu persatu kepada siswa dengan menggunakan metode tanya jawab sehingga terciptalah kondisi yang sesuai diinginkan maksud dari media gambar tersebut.

$$
\text { هذا كذاب ما هذا؟ }
$$

c) Al-hiwar al-muwajjah (dialog terpimpin)

Pada teknik ini diupayakan siswa dapat melengkapi pembicaraan yang sesuai dengan situasi tertentu dengan keadaan yang dilatihkan. Pada prakteknya guru dapat memberikan contoh tanya jawab dalam bahasa Arab, misalnya tentang shalat tarawih. Dalam tanya jawab ini guru memberikan kalimat-kalimat untuk dapat direspon oleh siswa, misalnya:

$$
\begin{aligned}
& \text { انا اريد أن أذهب الى مسج الكرامة بمرتافورا معك اريد أن أدهب الى مسجد } \\
& \text { الكرامة بمرتافورا هدالليل لصلات التراويح رو أنت ؟ } \\
& \text { لا ,لا أدهب الى هاك ,بل أذهب الى المصلى قريب من المدرسة }
\end{aligned}
$$


d) Al-tamtsil al-suluki (dramatisasi tindakan)

Pada teknik ini diharapkan siswa dapat mengungkapkan suatu aktivitas secara lisan. Guru melakukan upaya tindakan tertentu seperti tersenyum, tertawa duduk, dan sebagainya, kemudian siswa dapat memberikan jawaban sesuai dengan tindakan guru tersebut.

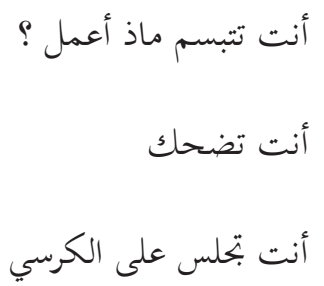

e) Tathbiq al-namadzij

Pada teknik ini diharapkan siswa dapat mengungkapkan kalimat lengkap melalui pola-pola kalimat yang belum disempurnakan. Melalui praktik pola dengan menyempurnakan kalimat tertentu yang didahului soal-soal yang tidak lengkap, acak, atau penambahan yang sudah lengkap. Dalam prakteknya dapat melalui pola kalimat antara lain penambahan, penyisipan, substitusi, integrasi, menyusun, melengkapi dan lain-lain.

2) Komunikatif adalah pola aktivitas dalam pembelajaran Maharah al-kalam yang lebih mengandalkan kreativitas para pelajar dalam melakukan latihan. Pada tahap ini keterlibatan guru secara langsung mulai dikurangi untuk memberi kesempatan kepada mereka mengembangkan kemampuan sendiri. Para pelajar pada tahap ini ditekankan untuk lebih banyak berbicara daripada guru. Sedangkan penyajian latihan diberikan secara bertahap dan dianjurkan agar materi latihan dipilih sesuai dengan kondisi kelas. Teknik yang dapat diterapkan dalam aktivitas komunikatif secara bertahap adalah sebagai berikut:

a) Percakapan kelompok (al-hiwar al-jama'i)

Dalam satu kelas para pelajar dibagi ke dalam kelompokkelompok sesuai kebutuhan. Setiap kelompok diberi judul cerita yang sederhana. 
b) Bermain peran (al-tamtsil)

Pada aktivitas ini guru memberikan tugas peran tertentu yang harus dilakukan oleh para pelajar. Peran yang diberikan harus disesuaikan dengan tingkat penguasaan bahasa para pelajar.

c) Praktik ungkapan sosial (tathbiq al-tabirat al-ijtima'iyyah)

Ungkapan sosial maksudnya adalah priaku-prilaku sosial saat berkomunikasi yang diungkapkan secara lisan, misalnya memberi hormat, mengungkapkan rasa kagum, gembira, ucapan perpisahan, dan lain-lain.

d) Praktek lapangan (al-mumarasah fi al-mujtama')

Praktik lapangan disini adaah bercakap-cakap dengan penutur asli bahasa Arab di luar kelas.

\section{Aktivitas dan Teknik dalam Pembelajaran Maharah Al-Kalam}

Kalam diidentikkan dengan penggunaan bahasa secara lisan. Faktor-faktor yang mempengaruhi berbicara secara langsung adalah : 1) pelafalan, 2) pilihan kata, 3) isi pembicaraan, 4) intonasi, 5) struktur kata dan kalimat, 6) sistematika pembicaraan, 7) cara memulai dan mengakhiri pembicaraan, dan 8) penampilan yaitu seperti gerak-gerik atau penguasaan diri.

Aktivitas latihan prakomunikatif adalah latihan-latihan yang memberikan maksud agar peserta didik dapat mempelajari kemampuan-kemampuan dasar dalam kegiatan maharah al-kalam seperti latihan penerapan pola dialog, kosakata, kaidah, mimik muka, dan sebagainya. Pada aktivitas ini keterlibatan guru dalam latihan cukup banyak berperan aktif dalam memberikan latihan yang di setiap unsur memerlukan banyak contoh.

Teknik yang dapat diterapkan dalam aktivitas latihan prakomunikatif secara bertahap adalah sebagai berikut:

a. Al-hifz ala al-hiwar (hapalan dialog)

Dalam teknik ini latihan meniru dan menghapalkan dialog-dialog mengenai berbagai macam situasi dan kesempatan. Melalui latihan ini diharapkan pelajar dapat mencapai kemahiran yang baik dalam percakapan yang dilakukan secara wajar dan tidak 
dibuat-buat. Kendatipun pada awalnya latihan ini dibuat secara pola berdasarkan hapalan, namun akan mencapai kemampuan berkomunikasi secara wajar jika hal ini dilakukan secara terusmenerus.

b. Al-hiwar bil al-shuwar (dialog melalui gambar)

Melalui teknik ini diharapkan dapat memahami fakta melalui gamar yang diungkapkan secara lisan sesuai denga tingkatan siswa, guru dalam hal ini membawa gambar-gambar dan menunjukkkan satu persatu kepada siswa dengan menggunakan metode tanya jawab sehingga terciptalah kondisi yang sesuai diinginkan maksud dari media gambar tersebut.

\begin{tabular}{|c|c|}
\hline هذ تلميذ & من هذا ؟ \\
\hline هذه استاذة & من هذه ؟ \\
\hline ذلك فلاح & من ذلك ؟ \\
\hline تلك طبيبة & من تلك ؟ \\
\hline اسمى عائشة & ما اسمك \\
\hline
\end{tabular}

\begin{tabular}{|c|c|}
\hline هذا كثاب & ما هذا؟ \\
\hline هذه كراسة & ما هذه ؟ \\
\hline ذلك باب & ما تلك ؟ \\
\hline تلك بحلة & ما تلك ؟ \\
\hline اسمي يوسف & ما اسمككّ \\
\hline
\end{tabular}

c. Al-hiwar al-muwajjah (dialog terpimpin)

Pada teknik ini diupayakan siswa dapat melengkapi pembicaraan yang sesuai dengan situasi tertentu dengan keadaan yang dilatihkan. Pada prakteknya guru dapat memberikan contoh tanya jawab dalam bahasa Arab, misalnya tentang shalat tarawih. Dalam tanya jawab ini guru memberikan kalimat-kalimat untuk dapat direspon oleh siswa, misalnya:

\begin{tabular}{|r|r|r|}
\hline التئn & \\
\hline
\end{tabular}

d. Al-tamtsil al-suluki (dramatisasi tindakan)

Pada teknik ini diharapkan siswa dapat mengungkapkan suatu aktivitas secara lisan. Guru melakukan upaya tindakan tertentu seperti tersenyum, tertawa duduk, dan sebagainya, kemudian 
siswa dapat memberikan jawaban sesuai dengan tindakan guru tersebut.

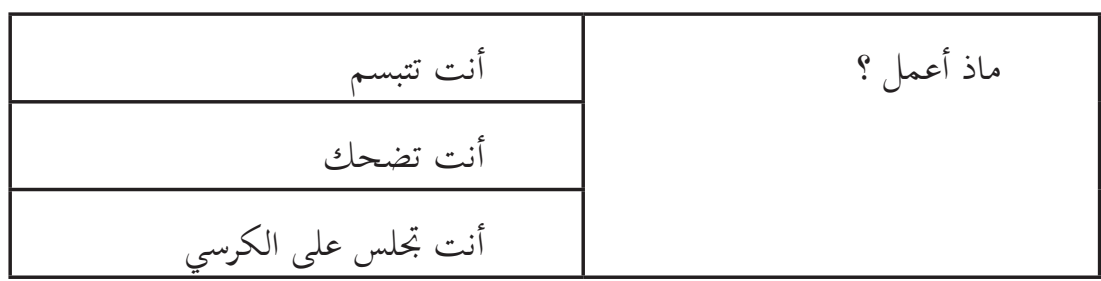

e. Tathbiqal-namadzij

Pada teknik ini diharapkan siswa dapat mengungkapkan kalimat lengkap melalui pola-pola kalimat yang belum disempurnakan. Melalui praktek pola dengan menyempurnakan kalimat tertentu yang didahului soal-soal yang tidak lengkap, acak, atau penambahan yang sudah lengkap. Dalam prakteknya dapat melalui pola kalimat antara lain penambahan, penyisipan, substitusi, integrasi, menyusun, melengkapi dan lain-lain.

1. Al-tazyid (penambahan)

\begin{tabular}{|c|c|}
\hline قرأ أحمد المجلة صباحا & \multirow[t]{3}{*}{ قرأ أحمد المحلة } \\
\hline قرأ أحمد البحلة مساء & \\
\hline قرأ أحمد المجلة ليلا & \\
\hline
\end{tabular}

2. Al-takhlil (penyisipan)

\begin{tabular}{|c|c|}
\hline ذهب التلميذ اليوم الى المكتبة & ذهب التلميذ الى المكتبة \\
\hline ذهب التلميذ بعد الظهر الى المككتبة & \\
\hline ذهب التلميذ قبل العصر المكتبة & \\
\hline
\end{tabular}

3. Al-tabdil (substitusi)

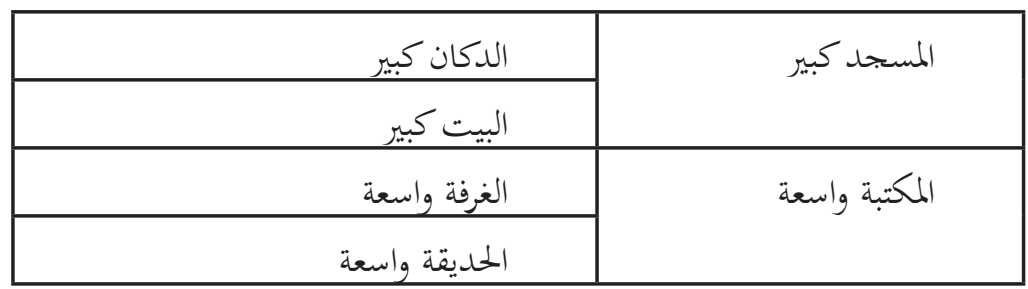


4. Al-tadmij (integrasi)

\begin{tabular}{|c|c|}
\hline & ذعرفت - التعلم مفيد \\
\hline & ذهفت أن التعلم مفيد السوق اليد \\
\hline
\end{tabular}

5. Al-tartib (menyusun)

\begin{tabular}{|c|c|}
\hline Kata tersusun & Kata Acak \\
\hline للعمدة اسافر الى مكة و المدينة مع اسرتي & اسكة - الى - للعمرة - اسافر - \\
\hline ذهب محمد الى المكتبة التجارية مع & 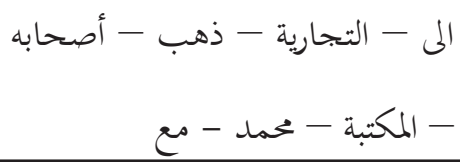 \\
\hline
\end{tabular}

6. Takmil al-jumlah (melengkapi kalimat)

\begin{tabular}{|c|c|}
\hline Pelengkap & Kalimat tak lengkap \\
\hline الموز & عثمان يحب البرتقال ولكن يحي يحب ... \\
\hline 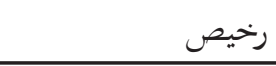 & هذا الكتاب غلي, وهذا الكراسة .... \\
\hline
\end{tabular}

Pola aktiftas pembelajaran maharah al-kalam pada tingkatan prakomunikatif menuntut pengajar/guru lebih dapat menyediakan materi yang lebih bervariatif sehingga akan membawa siswa lebih merasa belajar. Dengan teknik-teknik yang pada tahapan prakomunikatif diharapkan siswa dapat memahami pembelajaran dasar maharah al-kalam, sehingga dapat dilanjutkan dengan pembelajaran dengan teknik komunikatif.

\section{Kesimpulan dan Saran}

Pembelajaran bahasa Arab di Madrasah Ibtidayah juga mengembangkan keterampilan berkomunikasi baik secara lisan maupun tulisan, secara reseptif dan ekspresif untuk memahami, dan mengungkapkan informasi, perasaan serta pengembangan ilmu pengetahuan agama dan umum. Pengusaan empat skill merupakan target setiap pembelajaran bahasa termasuk bahasa Arab. 
Dalam pembelajaran bahasa arab, keterampilan berbicara mutlak sangat diperlukan, termasuk keterampilan menyimak dan berbicara saling berkaitan. Pola aktiftas pembelajaran maharah alkalam pada tingkatan prakomunikatif menuntut guru lebih dapat menyediakan materi yang lebih bervariatif sehingga akan membawa siswa lebih merasa belajar. Dengan teknik-teknik yang pada tahapan prakomunikatif diharapkan siswa dapat memahami pembelajaran dasar maharah al-kalam, sehingga dapat dilanjutkan dengan pembelajaran dengan teknik komunikatif. Teknik pembelajaran berbicara atau maharah al-kalam perlu dibina dan dikembangkan serta banyak latihan sehingga menumbuhkan minat siswa dalam berbicara (kalam). Guru seyogyanya hendaklah membuat setiap kegiatan pembelajaran yang dilakukan setidaknya memberikan kegairahan belajar bagi siswa, dan TPR dapat dijadikan sebagai salah satu metode untuk direkomendasikan dalam pembelajaran bahasa Arab.

\section{DAFTAR PUSTAKA}

Acep Hermawan, Metodologi Pembelajaran Bahasa Arab. Bandung : PT. Remaja Rosda Karya, 2011

Abd al-Rahman bin Ibrahim al-Fauzan, dkk, al-Arabiyyah Baina Yadaik, (Riyadh; Mu'assasat al Waqaf al-Islami, 2003)

Abdul Hamid, dkk. 2008, Pembelajaran Bahasa Arab, UIN Malang Press

Abu Bakar Muhamad, 1981, Metode Khusus Pengajaran Bahasa Arab, Surabaya: Usaha Nasional.

Ali Ridho, ttt المرجع في اللغة العرا بية في نحوها وصرفهاBeirut : Darul Fiqri Jus Awal

Ahmad Fuad Effendy, 2005, Metodologi Pengajaran Bahasa Arab, Malang: Fachrurrozi, Aziz dan Mukhshon Nawawi. 2010. تدريس أساليب Jakarta.

Chatibul Umam, 1980, Aspek-Aspek Fundamental Dalam Mempelajari Bahasa Arab, Bandung: PT Al-Ma'arif 
Rodifatul Chasanah - Total Physical Response (TPR)...

Desmita. 2005. Psikologi Perkembangan. Bandung: Remaja Rosdakarya. Effendy, Ahmad Fuad. 2009. Metodologi Pengajaran Bahasa Arab. Malang: Misykat.

Ehlers and Lee,1963, Crucial issues in education, united states America : Holt Rinehart and Winston

Fachrurrozi, Aziz dan Erta Mahyuddin. 2011. Teknik Pembelajaran Bahasa Arab. Tangerang.

Ghazali, Abdus Syukur. 2010. Pembelajaran Keterampilan Berbahasa dengan Pendekatan Komunikatif-Interaktif. Bandung: Refika Aditama.

Hasan, Muhammad Iqbal. 2002. Pokok-pokok Materi Metodologi Penelitian Aplikasinya. Jakarta: Ghalia Indonesia.

Hidayah, Aina Khusnul. 2008. Pengaruh Penggunaan Metode Total Physical Response (TPR) terhadap Pemahaman Kosakata Bahasa Jerman pada Anak Usia Dini di TK Akademika Tahun Ajaran 2007-2008. Skripsi tidak diterbitkan. Malang: Fakultas Sastra Universitas Negeri Malang.

Heri Guntur Tarigan, Berbicara Sebagai Suatu Keterampilan Berbahasa, Bandung: Angkasa, 1994

Imam Makruf, Strategi Pembelajaran Bahasa Arab Aktif, Need's Press, Semarang, 2009

Iskandarwassid dan Dadang Sunendar. 2008. Strategi Pembelajaran Bahasa. Bandung.

Kurnia, Fulan Dwi. Penggunaan Lagu untuk Meningkatkan Motivasi dan Hasil Belajar Bahasa Arab Siswa Kelas V SDI Surya Buana Malang. Skripsi tidak diterbitkan. Malang: Fakultas Sastra Universitas Negeri Malang.

Loise Ma'luf, Al Munjid fil Lughoh wal A'laam, Beirut: Dar el-Mashreq, 2005) Cet. 41.

Misykat. Mulyanto Sumardi,1974, Pengajaran Bahasa Asing (Sebuah Tinjauan Dari Segi Metodologis) Jakarta: Bulan Bintang

Murtadho, Nurul. 2008. Penyelarasan Materi dan Model RPP Bahasa Arab untuk Pendidikan Dasar dan Menengah. Jurnal Bahasa, Sastra, Seni (tahun 36, no 2) hal 221. 
Nurhidayati \& Ridwan, Nur Anisah. (Eds.). 2005. Strategi Pembelajaran Bahasa Arab untuk Anak. Malang: Program Due-Like Jurusan Sastra Arab Fakultas Sastra Universitas Negeri Malang.

Nana Sudjana, 1989, Dasar-dasar Proses Belajar Mengajar, Bandung : Sinar Baru

Radliyah Zaenudin, 2005, Metodologi dan Strategi AlternatifPembelajaran Bahasa Arab, Yogyakarta: Pustaka Rihlah Group

Sri Utari Subyakto-Nababan, Metodologi Pengajaran Bahasa, (Jakarta; Gramedia Pustaka Utama, 1993)

Slamet, 2003, Belajar dan Faktor-faktor yang mempengaruhinya Jakarta : Rineka Cipta

Suja'i, 2008, Inovasi pembelajaran Bahasa Arab, Semarang : Walisongo Press

Suryatna Rafi'i, 1985, Teknik Evaluasi, Bandung : Angkasa

Tarigan, H. G, DR, Prof. 1993. Pengajaran Kosakata. Bandung: Angkasa.

Tayar Yusuf Dan Syaiful Anwar, 1995, Metodologi Pengajaran Agama Dan Bahasa Arab, Jakarta: Raja Grafindo Persada

Zakiyah Daradjat, Metodik Khusus Pengajaran Agama Islam, Jakarta :Bumi Aksara

Zubaidah, Siti. 2009. Tarqiyyatu Mahaaratul Kitaabah Bistikhdaami Usluub al Kitaabah Addarbiyah (Derby Writing) fil Madrasah al Muthawassithah al Islaamiyyah Nurul Huda Malang. Skripsi tidak diterbitkan. Malang: Fakultas Sastra Universitas Negeri Malang.

Zuriah, Nurul. 2009. Metodologi Penelitian Sosial dan Pendidikan. Jakarta: Bumi Aksara. 
Rodifatul Chasanah - Total Physical Response (TPR)... 